\title{
Ethical Decision-Making in Family Firms: The Role of Employee Identification
}

\author{
Friederike Sophie Reck ${ }^{1} \cdot$ Denise Fischer ${ }^{1} \cdot$ Malte Brettel $^{1}$
}

Received: 8 April 2020 / Accepted: 9 February 2021 / Published online: 8 March 2021

(c) The Author(s) 2021

\begin{abstract}
The ethical behavior prevalent in an organization often determines business success or failure. Much research in the business context has scrutinized ethical behavior, but there are still few insights into its roots; this study furthers this line of inquiry. In line with identity work theory, we examine how employees' identification with a family business shapes internal ethical decision-making processes. Because it is individuals who engage in decision-making—be it ethical or not—our research perspective centers on the individual level. We followed an inductive, qualitative approach and conducted interviews with 19 employees in seven family businesses. We found that individuals engage in identity work when they identify as individual family firm employees and when they identify with the perceived characteristics of the family firm. These processes of identification, in turn, influence how employees cope with ethical situations. Our findings contribute to ethics and family business research, as well as to identity theory.
\end{abstract}

Keywords Family firms $\cdot$ Ethical decision-making $\cdot$ Identification process $\cdot$ Identity work

\section{Introduction}

The ethical behavior of organizations is gaining increased importance-especially in light of recent developments such as the Wirecard scandal or "Diesel Gate" (e.g., Fichter 2018; Kvalnes and Nordal 2018). Organizations engaging in ethical misbehavior may suffer from negative consequences such as financial or reputational losses (e.g., Lin-Hi and Blumberg 2018). Discrepancies between employees' own ethical values and those of their company may also lead to higher turnover rates, low organizational commitment, and lesser job performance (Hunt and Vitell 1986; Sharma 2018). Ethical behavior promotes a firm's reputation, which strengthens stakeholder relationships (e.g., Walsh et al. 2009) and

Friederike Sophie Reck

reck@time.rwth-aachen.de

Denise Fischer

fischer@time.rwth-aachen.de

Malte Brettel

brettel@time.rwth-aachen.de

1 Innovation and Entrepreneurship Group (WIN) - TIME Research Area, RWTH Aachen University, Kackertstr. 7, 52072 Aachen, Germany increases employee performance (Hunt and Vitell 1986; Sharma 2018).

According to recent research, family firms - the majority of existing businesses worldwide (Astrachan et al. 2020)—in particular tend to act more ethically than their non-family counterparts (Vazquez 2016). Castejón and López (2016) have shown, for example, that family firms are more aware of ethical situations due to responsible managers. Family firms are also more likely to exhibit benevolent tendencies towards overall societal well-being, which, in turn, promotes ethical behavior within the organization (Duh et al. 2010). Public examples of unethical family business conduct do exist; however, "the majority of research strongly suggests that family firms more typically strive for ethical behavior" (Astrachan et al. 2020, p. 638). In-depth research into the ethical behavior of family firms may result in valuable insights for the decision-making of other companies.

Such studies may also generate invaluable in-depth insights into ethical decision-making processes. Recent research applies an ethics-based view of family firms and highlights that shared beliefs, norms, experiences, and values are necessary for a values-based leadership style (Barbera et al. 2020). Other scholars find that a religious identity represents the most influential moral source of family business ethics (Dieleman and Koning 2020); they emphasize 
that such stewardship is often embedded in faith-based values (Carradus et al. 2020). Research has found that most family businesses behave more ethically than non-family firms and attributed this to (1) family involvement, (2) the specific personalities and values present in family firms, and (3) the specific social interactions among family members (Vazquez 2016).

Recent research, however, has focused more on comparisons of family and non-family firms or on the consequences of ethical behavior, rather than on its antecedents (Chau and Siu 2000; Peng et al. 2018; Rubino et al. 2017; Vazquez 2016). It reveals only limited insights into the roots of ethical behavior in family businesses (Astrachan et al. 2020). Although "ethical behavior must begin at the top" (Stead et al. 1990, p. 238), a better understanding of how individual employees adapt to and manage this behavior, especially when facing ethical dilemmas (Lehnert et al. 2015), is needed. While individuals "want to believe that others share [their] perceptions of what is honest and fair behavior, and thus, [their] understanding of ethicality, these [perceptions] are largely dependent on an individual's underlying principles and values" (Astrachan et al. 2020, p. 638). Individuals and their personal values, beliefs, and ideals clearly play a crucial role in coping with ethical dilemmas in business contexts; the same is true for an individual's socialization within an organization (Stead et al. 1990): After entering a firm, individuals embark on a journey of ongoing identification with the organization and/or its values, and their identity partly evolves and adjusts due to their organizational affiliation (Knapp et al. 2013; Kreiner et al. 2006). We therefore need clearer insights into how individual members identify with family firm characteristics and how this affects ethical decision-making in an organizational context. Dieleman and Koning (2020, p. 684) aptly state "identity work and actual (non)ethical business behavior is an important next step."

To examine ethical behavior in family firms, our work builds on the tenets of identity theory. Identity theory helps answer the question Who am I? and allows us to adopt an individual-centered perspective. The concept of identity work includes a vast range of activities to "create, present, and sustain identities" (Knapp et al. p. 334). In business contexts, an identity work perspective helps determine how an individual negotiates the questions of Who am I? and Who are we as an organization? (Kreiner et al. 2006). While familiarizing themselves with their organization's identity, employees perceive their firm's ethical system and compare the firm's ethical values to their own (Eury et al. 2018). Individuals often identify strongly with their organizations; this, in turn, significantly influences their identity development-including their values, ideals, and actions (Eury et al. 2018). An identity-focused lens is particularly useful in business context studies, as it centers on individuals' subjective interpretations of their work environment (Albert and
Whetten 1985). An identity perspective also allows us to examine how an individual's underlying principles and values shape her or his ethical system (Mcferran et al. 2010). It thus helps uncover the motivation for a particular individual behavior - in our case the decision to engage in ethical or unethical business conduct. We aim (1) to better understand how employees in family firms identify with their organization and (2) to explore how an employee's identification with a family firm shapes ethical decision-making processes.

To address our research questions, we applied an individual-centered perspective and interviewed 19 individuals in seven German family businesses. Our results indicate that employees of family businesses engage in identity work when they (1) identify as an individual family firm employee and when they (2) identify with perceived family firm characteristics. We show that an individual's identification with family firm characteristics (e.g., values, visibility of founding family, long-term orientation, socioemotional wealth) strongly shapes the individual's awareness of ethical issues.

Our study makes three contributions. First, we add to ethics research by devising a conceptual model and propositions that illustrate how coping with ethical decisionmaking is embedded in an individual's identity work. We uncover the drivers behind ethical behavior in the business context, thereby providing further insights into the roots of ethical business conduct. Building on this, we bridge the two perspectives of ethical decision-making and identity. We extend the literature on identity theory by detailing the interplay between individuals, their identification as family firm employees, and their identification with the organization. Specifically, we outline the aspects and characteristics constituting identity work among family firm employees. Finally, we expand family business research by emphasizing that the specific family firm characteristics play a crucial role in how employees identify with their organization and how they cope with (un)ethical situations.

\section{Theoretical Context}

\section{Ethical Decision-Making in Family Firms}

Scholars have created a large body of knowledge on family firm characteristics and behaviors (e.g., Anderson and Reeb 2003; Evert et al. 2016; Memili and Dibrell 2018; Pérez-González 2006). With family firm research expanding, scholars increasingly realized they needed to enhance the theoretical rigor of their studies (Hernández-Linares et al. 2018); however, a single clear-cut definition of family businesses would not cover their high heterogeneity (Memili and Dibrell 2018). Several approaches to such a definition exist, including degree of familiness, distinctive behavior, or family involvement and influence (Hogan, et al. 
2019). Most prominently, scholars have suggested that family firms' uniqueness fundamentally rests on the family's affective endowments in the organization-that is, their socioemotional wealth (Gómez-Mejía et al. 2007). We follow the definition that family firms are largely characterized by "the involvement of family members in the ownership and management of the firm, and the intertwining of family and business objectives" (Howorth et al. 2010, p. 438).

According to Astrachan et al. (2020, p. 637), family firms "represent a particularly rich and relevant context to re-assess the relationship between ethical beliefs, decisionmaking processes, and behaviors in business organizations." Research on ethical business behavior is gaining increased attention due to numerous ethical scandals, such as the Wirecard scandal or the Libor debacle (e.g., Sigh et al. 2012). Ethics is defined as "a system of value principles or practices and the ability to determine right from wrong" (Payne and Joyner 2006, p. 205). Ethical considerations are primarily concerned with the moral rightness or wrongness of decisions, as attested by a larger group of people, and only secondly with such decisions' legality. Unclear guidance, absence of laws and regulations, conflicting value systems, and uncertainty often lead to ethical dilemmas in which individuals or organizations are not certain how to decide on a course of action (Treviño 1986).

The characteristics of family firms differ from those of non-family firms and shape ethical decision-making processes (e.g., Berrone et al. 2010; Gómez-Mejía et al. 2007; Van Gils et al. 2014; Vazquez 2016). Earlier ethics-based research on family firms shows that the family's core values significantly influence the organization's ethical climate and culture (Duh et al. 2010). The founding family's traditions and their definition of organizational purpose shape the firm as well, thus affecting ethical decision-making (Duh et al. 2010; Dyer and Whetten 2006; Gallo 2004; Perrini and Minoja 2007). The family's value system also strongly affects decision-making in organizations (Blodgett et al. 2011; Duh et al. 2010; Everett 1986; Sharma and Sharma 2011), and religious values are especially important for family firms' ethical practices (Astrachan et al. 2020; Kavas et al. 2020). Faith-oriented organizational practices, for instance, shape the development of stewardship (Carradus et al. 2020) or philanthropic activities in family firms (Bhatnagar et al. 2020).

In addition to values, family firms' non-financial objectives and socioemotional wealth perspective promote ethical behavior (e.g., Gómez-Mejía et al. 2007; Sharma and Sharma 2011). A family's and its firm's reputations are closely linked, so family firms strongly focus on preserving their good standing (Kashmiri and Mahajan 2014) with "a tradition of socially responsible business practices" and avoiding "harmful practices that can besmirch the image of the firm" (Dyer and Whetten 2006, p. 791). Some scholars argue - from a social capital and stakeholder theory perspective - that family firms strive for socially responsible actions (McGuire et al. 2012). Long and Mathews (2011), from their social exchange perspective, state that reciprocity in social exchange is important for developing cohesion in the family firm's distinctive ethical frame.

Family firms lean towards ethical behavior (e.g., Astrachan et al. 2020), but there is still little insight into how employees come to implement the founding family's ethical values in their daily activities and which internal mechanisms are at play (Krishnan and Peytcheva 2019; Vazquez 2016). It is not the family firm as such that "exerts moral responsibility, but rather the individual members of the corporation" (Stead et al. 1990, p. 412). Given this insight, it is essential to adopt an individual-centric perspective to uncover the drivers of ethical behavior. An identity theory approach is particularly valuable in this context as "[m]oral identity is rooted in social identity theory" (Treviño et al. 2014, p. 648) and "one's social identity can influence ethical decision making" (Cremer et al. 2010, p. 4). In the following section, we detail the identity work perspective and link it to ethical decision-making in family firms.

\section{Identity Work and Ethical Decision-Making in Family Firms}

The concept of identity manifests itself on three different levels: individual, social, and organization (Pratt et al. 2016). Individual identity revolves around the questions Who am I? and How should I act? and thus implies an individual's particular values, feelings, and behaviors (Alvesson et al. 2008). Social identity is defined as "that part of an individual's self-concept which derives from his knowledge of his membership of a social group (or groups) together with the value and emotional significance attached to that membership" (Tajfel 1978, p. 63). Social identity theory concerns intergroup processes and the derivation of identities from the groups to which individuals belong (Stets and Burke 2000). Organizational identity is a self-reflective construct aiming to answer the question of Who are we? as an organization (Albert and Whetten 1985). It draws on the central, enduring, and distinct features of the organization (Albert and Whetten 1985).

Employees' individual identities are embedded in an organizational context, and individuals use this context to construe subjective meanings and experiences by identifying with the organization (Alvesson et al. 2008). According to Kreiner et al. (2006, p. 1032), identification refers to a "process of aligning identity with that of a social group," and organizational memberships shape social identities. This identity construction implies that the individual strives for a "situated sense of an entity" to ensure effective interaction with other individuals or 
groups in the long run (Albert et al. 2000, p. 13). The theoretical concept of identity work makes it possible to uncover "people's engagement in forming, repairing, maintaining, strengthening, or revising their identities" (Ibarra and Barbulescu 2010, p. 137). Forms of identity work vary from, for instance, balancing multiple identities or experimenting with identities to expressing identity problems (Ibarra and Barbulescu 2010). The concept of identity work also includes an individual's processes of identifying with an organization. For instance, employees "engage in identity work in order to negotiate and optimize the boundaries between personal and social identity" (Kreiner et al. 2006, p. 1032). Hence, the perspective of identity work allows a dynamic view of how employees identify with their organization.

As argued above, an individual's approach to coping with ethical dilemmas is not solely driven by personal identity, values, beliefs, and ideals (Astrachan et al. 2020; Stead et al. 1990). Ethical decisions are always embedded in an environment-even if the individual, as such, makes the (un)ethical decision. Based on social identity theory, individual employees develop their moral identity through identity work and compare the firm's ethical values to their own; this also applies when they face an (un)ethical situation in an organizational context. Moral identity refers to an individual's self-conception in relation to a set of moral traits and is a "mental representation of one's character that is held internally and projected to others" (McFerran et al. 2010, p. 40). Past research shows that organizational infrastructure-such as ethical climate (Cullen et al. 1993), ethical culture (Treviño 1990), and the leadership team and its way of leading the organization-especially affects ethical decision-making (Brown et al. 2005; Treviño and Brown 2004).

Dieleman and Koning (2020) reveal how, for family businesses, leaders' identity work is shaped by personal and organizational values, which have been shown to influence the articulation of family business ethics. However, the authors emphasize that a deeper understanding of the roots of ethical behavior is needed; they call for future research to apply an identity work perspective to explore (un)ethical behavior, as well as "the relegation of values into shared values in more depth" (Dieleman and Koning 2020, p. 685). The founder family's value systems especially "foster strong identification among members" (Sundaramurthy and Kreiner 2008, p. 415).

Family firms thus offer a very promising context to examine ethical behavior from an identity work perspective: (1) They aspire to implement ethical behavior (Astrachan et al. 2020), and (2) their employees strongly identify with the organization due to the specific family firm characteristics, such as a strong sense of oneness and shared destiny (Zellweger et al. 2010).

\section{Methodology}

\section{Context and Research Design}

We conducted interviews with individuals employed by family firms based in Germany. All of our interviewees thus draw on the same set of underlying national norms, values, and traditions (Lubinski 2011). Germany has a well-developed mid-tier in which almost 91 percent of businesses are family firms (Gottschalk et al. 2017; Peng et al. 2018). The majority of these medium-sized companies were founded by families who share the Christian beliefs of an honest merchant and have been owned by the respective families for generations (Palazzo 2002). To reflect a wide variety of family firm characteristics in our dataset (Knapp et al. 2013), we selected a broad range of family firms in terms of size, age, industry scope, and geographic location in Germany. We defined a family firm as a business where the founder family or later generations hold the majority of the shares and is/are either present in the management or in the supervisory board (Howorth et al. 2010). We also asked our interviewees to describe their employing organization; all of them affirmed they work in a family firm (Howorth et al. 2010).

To study how family firm employees identify with their organization and how this identification affects ethical decision-making, we used an exploratory qualitative research approach (Charmaz 2014; Miles and Huberman 1994; Yin 1994). More precisely, our research encompassed seven comparative multiple-case studies (Eisenhardt 1989). A qualitative research design was especially appropriate for our purpose as there is scarce present theory explaining the relationship between employees' identity work and ethical decision-making. Furthermore, we focused on how questions rather than on what or how many questions (Yin 1994). This qualitative research design allowed us to detect the drivers of (un)ethical behavior. Our approach followed earlier research that identified qualitative research designs as adequate for studying the unique dynamics and characteristics of family firms (Chenail 2009; De Massis and Kotlar 2014; Fletcher et al. 2016; Leppäaho et al. 2016). The approach helped us reflect on interviewees' subjective perception and its interpretation (Charmaz 2014; Gephart 2004). It also supported scholarly flexibility and creativity and provided analytical tools for the profound assessment of a topic (Bansal and Corley 2012; Fletcher et al. 2016; Pratt 2009).

\section{Sampling}

We conducted interviews with 19 employees in seven German family firms ranging in size from 700 to 15,000 
employees. All firms share the national context, produce goods and services, and are not pure service providers, but act in different industries. This variety allowed us to gain insight into employees' identification and ethical decisionmaking in diverse industries. We thus also ensured there was no bias due to a single-industry focus. We interviewed employees in positions from entry-level to senior management. Creating our sample, we followed the theoretical sampling approach (Charmaz 2014): we collected relevant data and refined the categories of data collection while our theory was emerging. Our aim was to understand in more detail how individuals identify with their organization and if such identification influences employee behavior in (un) ethical situations. To this end, we interviewed employees in procurement, marketing, and sales-all functions that assumedly involve interactions with many external stakeholders and are thus prone to the occurrence of ethical dilemmas (Dubinsky and Loken 1989; Ferrell et al. 2013; Gorsira et al. 2018). To obtain a holistic view of the employees' identity work and ethical decision-making, we interviewed a minimum of two people per organization. Table 1 presents an overview of the companies and the interviewees.

\section{Data Collection}

We collected our data mostly during visits to the companies' headquarters in the fall of 2018 and the spring of 2019. For one company, this was not possible due to travel and time constraints. We therefore conducted all interviews with this company by phone. Two other interviews were also done by phone due to interviewees' time constraints. We followed a semi-structured interview protocol based on an extensive review of the literature on ethical decision-making (e.g., Craft 2013; Jones 1991; Lehnert et al. 2016; Rest 1986; Schwartz 2016; Treviño et al. 2006) and identification (e.g., Albert et al. 2000; Kreiner et al. 2006; Pratt et al. 2016). We developed a first draft of our semi-structured interview protocol prior to the interviews and tested it with a sample interview.

The protocol covers two parts: The first part serves to obtain information on identity aspects and inquires, for example, about the individual identity of the employees, their background, and their position in the organization. In addition, we assessed the role of the family within the firm and the interviewee's perception of this role. In the second part, we discussed ((un)ethical) decision-making within the organization; we started with the general decision-making process and transitioned to ethical dilemmas the interviewees might have faced. If they had not encountered any ethical issues within their career, we focused on their definition of ethical behavior and how they would react if they were confronted with such behavior. The interviews lasted between
30 and $60 \mathrm{~min}$ and were all recorded with the approval of the interviewees. All audio-taped interviews were transcribed verbatim to ensure high levels of reliability. To complement the interviews and to be able to triangulate the subjective verbal statements with formal communication (Charmaz 2014), we also collected official written material such as company brochures, codes of conduct, or information on company websites.

\section{Data Analyses}

We analyzed the interviews in four steps. First, we derived the codes inductively from the interviews (e.g., Kreiner et al. 2009). We had no pre-defined set of codes when we started the coding process. Having conducted a literature review, we structured our approach around a first set of general themes on identification and ethical decision-making (Smith 2014). In this first step, two researchers worked individually and independently on the summary and line-by-line coding of the interviews. Second, the two researchers compared their coding and derived higher-level codes. This was an iterative process - the higher-level codes and categories were altered and discussed again when new codes emerged from one interview to the next. For interview coding and analyses, we used the well-established coding software $f 4$ transcript and $f 4$ analysis. Third, we derived our final coding dictionary, which was the result of the iterative discussions between the two researchers (Charmaz 2014). Fourth, we created categories (second-order codes); these categories consisted of our first-order codes, but were more theory driven (Gioia and Chittipeddi 1991; Knapp et al. 2013). With this, we linked our data analyses to theory-which allowed us to extend existing research and contribute to new research ideas (e.g., Charmaz 2014; Knapp et al. 2013; Smith 2014).

\section{Findings}

Our first research question addresses how employees in family firms identify with their organization and applied an individual-centric perspective to uncover the drivers behind identification processes. Two identification processes emerged from our data: (1) identification as an individual family firm employee and (2) identification with perceived family firm characteristics. We acknowledge that individuals actively undergo processes of identification by engaging in identity work. Our second research question aims to understand how an employee's identification with the family firm affects ethical decision-making processes. In our model (see Fig. 1) and in this section, we show that coping with ethical decisions in family firms is embedded in and thus influenced by individuals' identity work. Identity work as 


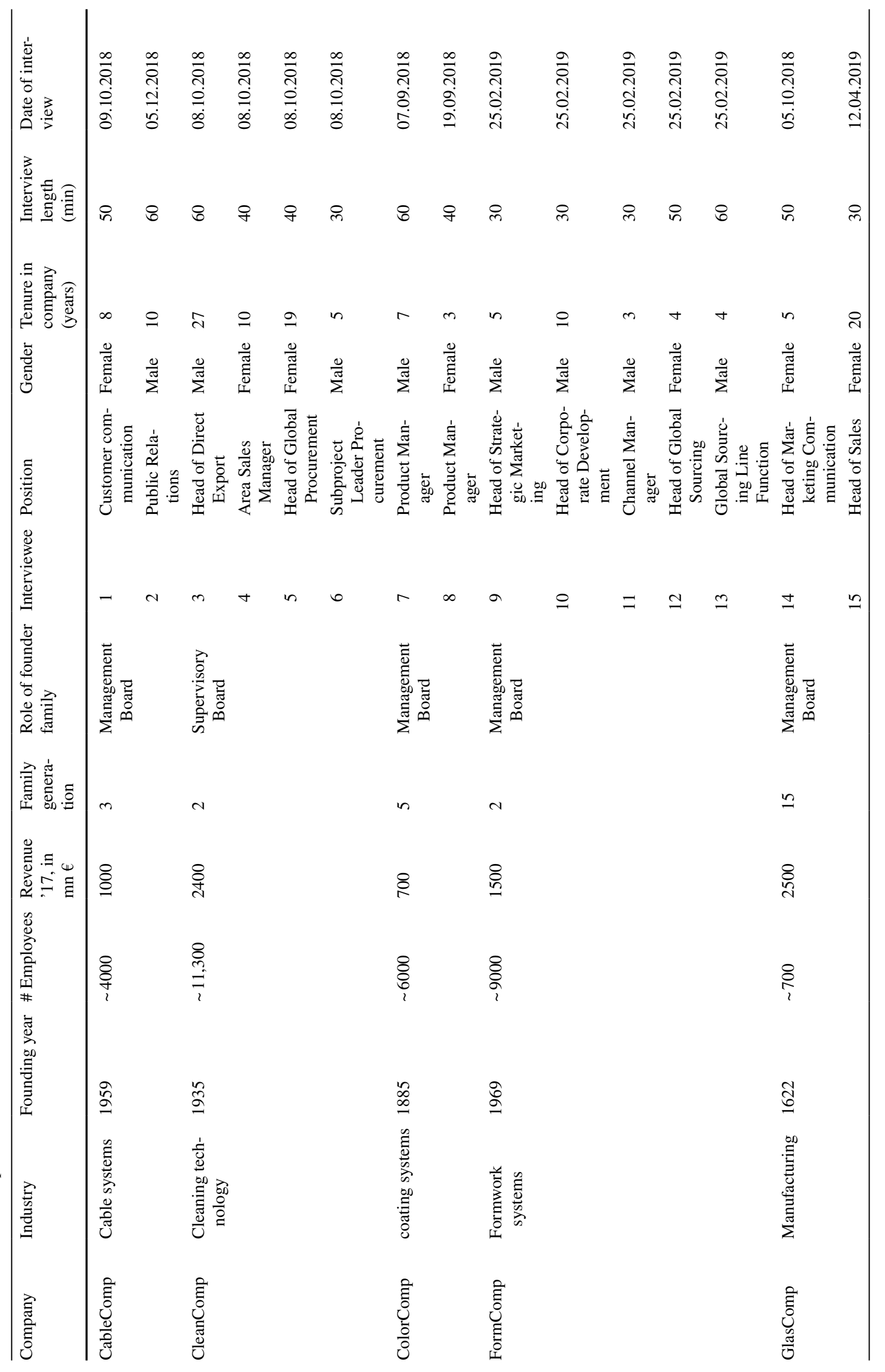




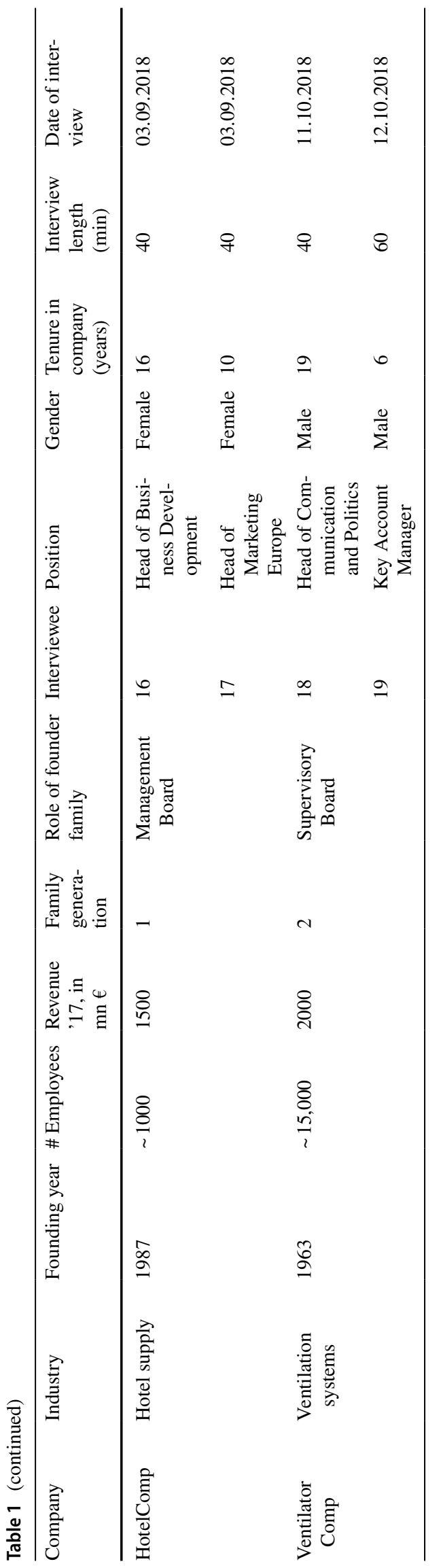

such is anchored in the specific context of the family firm, which we elaborate below.

We focus our research on German family firms. This cultural context shapes the identity work of employees and guides both their ethical awareness and how they cope with ethical questions. In Germany, family firms operate within a framework of clear laws and regulations and a stable economic landscape (Lubinski 2011); they therefore act in a sound environment with transparent guidelines of what is legally right or wrong. German family firms are mainly managed by families who value the norms and traditions according to the Christian faith (e.g. Fathallah et al. 2020). These shared values inform the thinking, identification processes, and ethical awareness of members of the founding family and employees. Family as a social construct also shapes German culture (Mayer et al. 2012). When compared to Southern European countries such as Spain, the social construct of a family is not as dominant in German national culture, but the values attached to a family are still held in high esteem (Colli et al. 2003).

\section{Identification as individual family firm employee}

Our interviews and data analyses allowed us to conclude that it is highly important for individual employees in a family firm to identify as an employee of such an organization and be a part of it and that this influences how they perceive ethical decision-making. Our data revealed three aspects shaping an individual's identity work: (1) employee's freedom of decision within the organization; (2) blending of private and professional life; and (3) shared and common values of individual employee and founding family. Table 2 provides an overview of codes and exemplary quotations.

(1) Freedom of decision: The freedom of decision enables employees to assume responsibility and this entrepreneurial spirit motivates employees to join the organization, as illustrated by the example of the Head of Strategic Marketing, FormComp.:

For me, the main reason to join the company was that you could help shape the content. \#9, Head of Strategic Marketing, FormComp.

A combination of freedom of decision and management support (e.g., in the form of trust) is also important for individuals to identify as family firm employees. Independent decision-making and various day-to-day tasks need to be supported by the management:

I have a lot of freedom. [...] And my bosses and superiors trust me and my experience and knowl- 
Fig. 1 Ethical decision-making and identity work

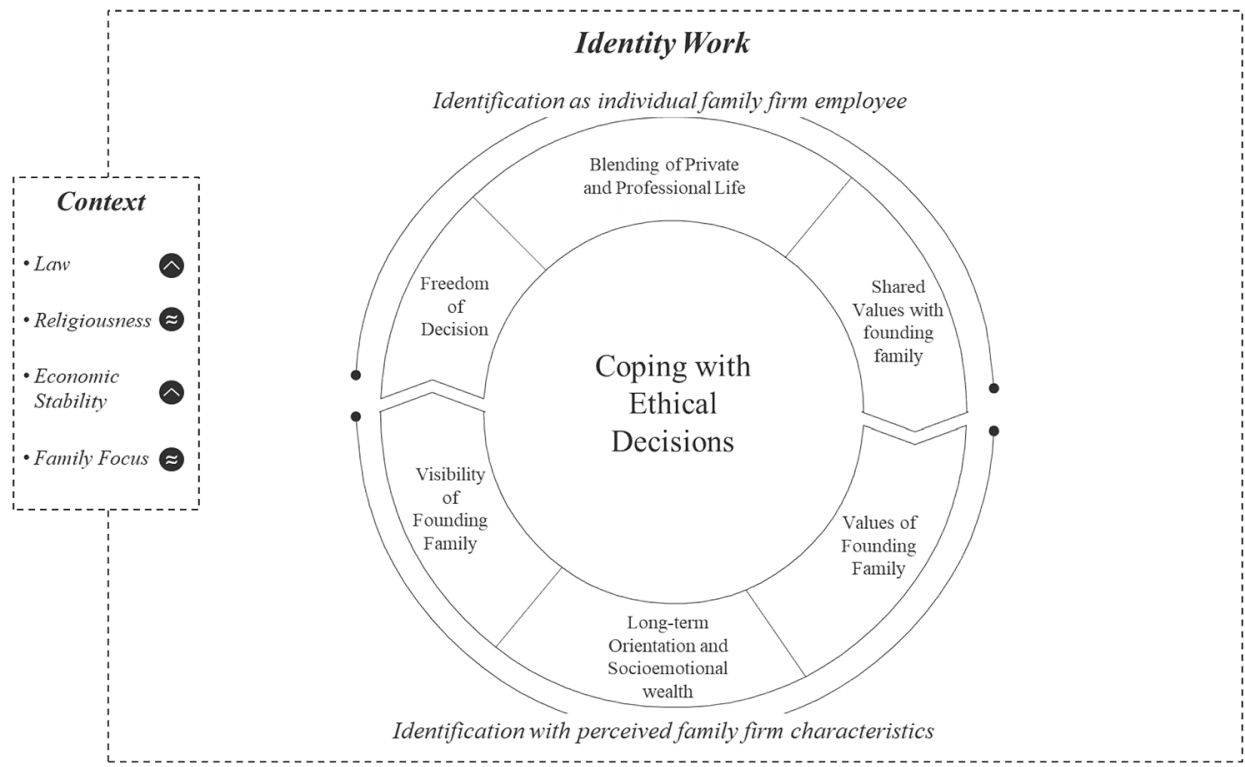

$\boldsymbol{\approx}$ Neutral characteristic

Pronounced characteristic edge. \#5, Head of Global Procurement, CleanComp.

(2) The blending of private and professional life: Most interviewees prioritize family and private life over their professional life. However, all of them strive for meaning in their professional life and emphasize how important it is to them that their employer considers their rivate life and supports the blending of private and professional dimensions:

"[...] we not only work as team, but we also spend our free time together. [...] I could not work in isolation. For me, personal relationships are very important, and the organization provides me with these relationships, which makes me very happy. \#19, Key Account Manager, VentilatorComp.

Family firm employees seem to perceive a strong blending of their private and professional lives. This might lead to decision situations in which the individual employee (more easily than in other organizational forms) takes on not one, but two roles: that of a private person and that of an employee. The role of private person, with a family and/or a circle of friends, is also present when individuals make business decisions in their professional life, so an employee's approach to ethical business decisions is not solely driven by her/his role in a firm, but rather by an overlap between private and professional roles.

(3) Shared values with founding family: For an employee to identify with the organization, it is crucial that the founding family's values are congruent with the indi- vidual's values. Two interviewees explained how important value congruence is for personal satisfaction at work:

My values and those of the organization are congruent. Otherwise I would be unhappy in the long run. \#6, Subproject Leader Procurement, CleanComp. Yes, my values are reflected by those of the organization. I can identify with them very strongly. \#10, Head of Corporate Development, FormComp.

Three values - trust, transparency, and loyaltyfoster congruence between employee and organization value systems. Employees want to feel trusted, and they also want to be able to trust the company. Trust is transferred to the organization by the founding family and their long-lasting commitment towards the organization. Transparency is a value that is highly important for all employees, because it ensures open communication within the organization. Transparency modeled by the founding family promotes similar behavior among employees. Many interviewees also stated that loyalty is an important value in their professional life. An organization's loyalty towards employees creates a safe working environment without fear. This ensures the individual's identification with the organization. As one interviewee shared:

Loyalty is a big word, but I think I really felt like a part of the companies I have been working for. I want to be seen in the best light, and I want to help 
Table 2 Identification as individual family firm employee

\begin{tabular}{|c|c|c|}
\hline Quotes & 1st Order codes & 2nd Order categories \\
\hline $\begin{array}{l}\text { "That's perhaps how I would imagine the perfect company, } \\
\text { because each division is forced to act autonomously and } \\
\text { entrepreneurial. Because by bundling all the competencies } \\
\text { in the respective area, you can make the best possible use of } \\
\text { them." [\#6 CleanComp.] }\end{array}$ & \multirow[t]{3}{*}{ Entrepreneurial spirit } & \multirow[t]{9}{*}{ Freedom of decision } \\
\hline $\begin{array}{l}\text { "For me, the main reason to join the company was that you } \\
\text { could help shape the content. That is often not necessarily } \\
\text { the case in companies. Because you actually have to adjust } \\
\text { to already existing structures." [\#9 FormComp.] }\end{array}$ & & \\
\hline $\begin{array}{l}\text { "And there are new tasks to do every day, my day-to-day } \\
\text { work has a lot of variety. You can be creative and if you } \\
\text { have new ideas, you can put them into practice, which is } \\
\text { then accompanied by IT, which is also very exciting. You } \\
\text { can put your own stamp on it and say hey, I helped develop } \\
\text { it. This is actually quite a lot of fun." [\#1 CableComp.] }\end{array}$ & & \\
\hline $\begin{array}{l}\text { "I can shape things and make decisions. And I am really sup- } \\
\text { ported by the management and owners. It motivates me that } \\
\text { my ideas are taken serious. This is great." [\#15 GlasComp.] }\end{array}$ & \multirow[t]{2}{*}{ Freedom but support by management } & \\
\hline $\begin{array}{l}\text { "I have a lot of freedom. So as long as I save money in the } \\
\text { interest of the company and keep the production running, I } \\
\text { can decide many things. And my bosses and superiors trust } \\
\text { me and my experience and knowledge." [\#5 CleanComp.] }\end{array}$ & & \\
\hline $\begin{array}{l}\text { "In this organization, you have a very high degree of free- } \\
\text { dom, you can achieve a lot, you can decide a lot.” [\#18 } \\
\text { VentilatorComp.] }\end{array}$ & \multirow[t]{3}{*}{ Independent decision-making } & \\
\hline $\begin{array}{l}\text { "For myself, I like a lot of personal responsibility. I prefer a } \\
\text { long leash and I am also willing to give these degrees of } \\
\text { freedom to someone else." [\#7 ColorComp.] }\end{array}$ & & \\
\hline $\begin{array}{l}\text { "That I have a great degree of freedom to make decisions. I } \\
\text { don't have to get everything approved and coordinated, but } \\
\text { I really do have a lot of leeway in my team, where I can } \\
\text { decide for myself what I can do.” [\#17 HotelComp.] }\end{array}$ & & \\
\hline $\begin{array}{l}\text { "To see how you can bring such an area forward through } \\
\text { your own activities is what I enjoy. Together with the high } \\
\text { degree of creative freedom at various points to influence } \\
\text { this." [\#8 ColorComp.] }\end{array}$ & Variety in the daily work & \\
\hline
\end{tabular}


Table 2 (continued)

\begin{tabular}{lll}
\hline Quotes & 1st Order codes & 2nd Order categories
\end{tabular}

"Family is the center of my life. I have two kids. I'm married. Family has priority over business life Sure, so I like my job. It's important that you like it. But I always say that a job is for working life, a family is for life, ideally." [\#11 FormComp.]

"My personal life is a bit more important at the moment. I just became a father. Maybe I would allocate $40 \%$ of my time to the family at the moment. Or maybe the family $50 \%$, $45 \%$ to the job, and the rest I would give to leisure time." [\#10 FormComp.]

"I think the job is important, but the private life is more important to me." [\#17 HotelComp.]

"Since I really enjoy my work very much, I definitely dedicate half of my time to work. Yes. And the other half is shared by family and friends." [\#6 CleanComp.]

"I dedicate the main part of my time to work. Let's say $60 \%$ work, 20\% family, 20\% friends.” [\#13 FormComp.]

"I like doing my job. This is not a dramatic problem for me. Sometimes I think about work at home or I talk to my husband about work.” [\#14 GlasComp.]

"If I really wanted it, I could dedicate more than $50 \%$ of my time to family and friends. But normally the business is a bit more than family and friends. And it is exactly this balance which one needs to fight for. I also tell this to my employees. We found a solution in our organization: flexible working models. And we consider this as important. [...] Even the managing family member who is travelling for business $100 \%$ finds time to harvest grapes in his own wine yard." [\#3 CleanComp]

"I still want to have a bit of separation between private and professional life.” [\#18 VentilatorComp.]

"[...] we not only work as team, but we also spend our free time together. [...] I could not work in isolation. For me, personal relationships are very important and the organization provides me these relationships, which makes me very happy." [\#19 VentilatorComp.] 
Table 2 (continued)

\begin{abstract}
Quotes
"Yes, my values are reflected by the ones of the organization. We had a value project two years ago [...] and I agree with all these values in one way or the other. I can identify with them very strongly." [\#10 FormComp.]

"I couldn't work for a company whose products I'm not convinced of. [...]. This is simply something where you have to be able to identify with your own values. And with this company I succeed in doing this almost 100\%." [\#3 CleanComp.]
\end{abstract}

"Yes, my values and the one of the organization are congruent. Otherwise I would be unhappy in the long run." [\#6 CleanComp.]

"My personal values are actually not far away from the company's values." [\#9 FormComp.]

"For me, the topic of teamwork, the topic of togetherness, the topic of appreciating each other is really important. It actually also fits in with the fact that you don't try to do something individually, you are a team, you have the same opinion and you actually want to achieve something together." [\#11 FormComp.]

"So for me team orientation is absolutely important." [\#15 GlasComp.]

"I believe that I am relatively competitive in my basic attitude. However, this is combined with possibly old-fashioned values." [\#10 FormComp.]

"I do need a certain level of leadership for myself. I also need to be able to trust my managers to know what the future holds. If everyone had a say, I would have the feeling that a lot of dilettantes." [\#5 CleanComp.]

"The fourth value is transparency for me. We are a large team and you cannot focus on everyone all the time. [...] Transparency helps to communicate with each other and to address pain points. You know what the other person thinks and feels." [\#15 GlasComp.]

"Loyalty is a big word, but I think I really felt like a part of the companies I have been working for. I want to be seen in the best light and I want to help the organization. If you can combine both aspects, you can support your own career and the interests of the organization. This is important to me. And I think this is loyalty." [\#11 FormComp.]

"Yes, it is important to work in a reliable environment. To work independently is also important to me." [\#13 FormComp.]

"Then in any case reliability is important. This is a value for me where I say the employees can rely on me, if they have a topic, they can always come to me. And the other way round, I say that people can rely on my employees, if they tell me that, then that's the way it is. We need to trust each other." [\#15 GlasComp.]

1st Order codes 2nd Order categories

Personal values match company values Shared values with founding family

Teamwork

Traditional value system

Transparency and loyalty

Trust and engagement 
the organization. If you can combine both aspects, you can support your own career and the interests of the organization. This is important to me. And I think this is loyalty. \#11, Channel Manager, FormComp.

Loyalty from the organization towards employees was also frequently mentioned, for example:

The family business is very strongly influenced by the advisory board, by the family, and has a long-term perspective. They don't just look at profits in the short term: they are long-term oriented [...]. Also, they are loyal and take the employees with them. To me, this is very special. \#12, Head of Global Sourcing, FormComp.

Thus, our first proposition is as follows:

Proposition 1 Individuals identify strongly as an employee of a family firm if they have freedom of decision, blend their private and professional lives, and share values with the founding family.

\section{Identification with Perceived Family Firm Characteristics}

Our data also reveal that individuals, as part of their identity work, not only identify as family firm employees, but also with perceived family firm characteristics. We found three family firm characteristics that principally affect employees' identity work and ethical decision-making: (1) founding family values; (2) long-term orientation and socioemotional wealth; and (3) founding family visibility within the organization. Table 3 displays exemplary codes and quotes for these three family firm characteristics.

(1) The values of the founding family: As described, values shared with the family firm are crucial for an individual to identify strongly as a family firm employee (value congruence). Our analysis also shows that the values lived and emphasized by the founding family shape employees' identity work. This goes beyond value congruence. The founding family's values form the normative framework (i.e., the value system) in which employees operate. Employees perceive how strongly the founding family takes care of and focuses on the employees within the organization. In this context, most of our interviewees mention that their company culture is shaped by the founding family, which is reflected in a strong sense of care for the organization. As one interviewee phrased it:
It [i.e., the identity] is still characterized by the founder family. Their spirit is still in every corner of the organization. \#3, Head of Direct Export, CleanComp.

Furthermore, the humility of the founding family impresses most of the interviewees. They characterize the family as down-to-earth, humble, and very approachable by all employee levels. With this behavior, the founding family often acts as a role model for employees. Local roots are important to many founding families and they promote local connectedness, which makes employees proud to work for the organization. These values, which are closely linked to the private life of employees, support employee identification with the firm and create a sense of belonging. As one interviewee stated:

The close connection with the region is important. We have our roots here. The founder family wants to provide consistency to the region and the employees. And our company culture emphasizes the closeness to the founder family. \#14, Head of Marketing Communication, GlasComp.

This connection between the managing family and their employees helps establish trust, which is probably the most important value because it facilitates identity work and thus identification with the organization. Employees who feel connected to the management team or owner trust the executives' decisions and strategic directions. They feel responsible for organizational decisions and behavior because they do not want to disappoint the family's trust. Trust acts as an informal management mechanism in family firms; it guides employee behavior and decision-making.

(2) Long-term orientation and socioemotional wealth: We conclude from the interviews that family firms' long-term orientation very strongly contributes to employees' identification with the organization. Longterm orientation promotes trust in the organization as employees perceive long-lasting career opportunities. It is thus also important to identify with the family firm's tradition and different family generations when identifying with the organization. One interviewee states:

So, you still experience that the bond to the company is very strong. [...] Now the generation of the founder's son and his siblings manage the organization. They are very present in the organization and so is their history. \#12, Head of Global Sourcing, FormComp. 
Table 3 Identification with perceived family firm characteristics

Quotes
"For me, it matters that it's still family-run. The founder's
wife-at 87 years—is still very committed to the organization.
She still makes speeches at events and says how important the
family is, how important the support of a partner is, even if you
work a lot. And she still transports the family's values, like the
importance of the health and the family." [\#1 CableComp.]
"The founder is still part of the board of directors. And he's just
out and about in the house and sometimes bursts in somewhere.
Also he cares for the topics which are relevant for the organiza-
tion and tells what he thinks about critical issues. Sometimes
you get a scanned, handwritten letter from him." [\#7 Color-
Comp.]
"The owner family lives for the company with body and soul.
The company is the lifework of the family and you can feel it.
You can feel it totally. We have short decision paths. If I need
to talk to one of the family members, I could always call them."
[\#15 GlasComp.]

"The family creates some closeness for the people and a kind of identification. Because you do not only meet formally in the company, but also informally. For example, on a Saturday afternoon at a soccer match." [\#14 GlasComp.]

"I feel the family presence in my daily work when it comes to topics that move the family very strongly, such as an important trade fair which is now coming up. This is also a very important topic for the family, because you also represent yourself externally." [\#12 FormComp.]

"I perceive a certain openness in the organization. And this openness supports short communication paths. For example, the founder's son was present in my second interview round with the company. He is also very present at the trade fairs of our company. And I also attended a conference with the founder. There he impressed me with his level of operational readiness in technical meetings and him continuous interest in our day-today operations." [\#19 VentilatorComp.]

"Of course, the owning family sometimes is involved at a different level than a pure external management team would be. Sometimes the founder gets involved in topics you simply can't believe. [...]. For example, he decides about the design of the packaging of our new product launch." [\#8 ColorComp.]

"Well, for one thing, they're just really present in many places. So they are not silent partners in the background, but they are really active in the operative business. Currently, three family members are officially in management positions." [\#2 CableComp.]

"The family always invests the money back into the company. They could have a yacht in St. Tropez, five holiday homes and

1st Order codes

Family with great visibility in organization 2nd Order categories

Family present inside and outside the company

Family very present in day-to-day business a private jet. Not at all. The founder's son cycles to the office in the summer and drives a B-class. So really down-to-earth people. They also say they don't see the company as their property, but as an obligation to continue, to preserve it, to grow as much as possible. And this spirit, this attitude, of course, helps us all tremendously." [\#3 CleanComp.]

"Then as now, inventiveness, a feeling for the right economic decision at the right time and responsibility for the safety and well-being of people and the environment were in the foreground" [Sustainability brochure, ColorComp.]
Family's money stays within the organization

Long-term orientation and socioemotional wealth
Based on tradition 
Table 3 (continued)

\begin{tabular}{|c|c|c|}
\hline Quotes & 1st Order codes & 2nd Order categories \\
\hline \multicolumn{3}{|l|}{$\begin{array}{l}\text { "Down-to-earth. Open-minded. We want to be big, but you still } \\
\text { want to show where we come from. We want to be in the little } \\
\text { village where we have our headquarter and not somewhere } \\
\text { in Ulm or Stuttgart or Munich. We want to be constant. We } \\
\text { are proud of what we have achieved and we want to help our } \\
\text { customers with this knowledge." [\#11 FormComp.] }\end{array}$} \\
\hline $\begin{array}{l}\text { "We are aware that our goal as a company to become a model } \\
\text { of sustainability in our industry in Europe cannot be achieved } \\
\text { overnight." [Sustainability brochure, ColorComp.] }\end{array}$ & Long-term orientation & \\
\hline \multicolumn{3}{|l|}{$\begin{array}{l}\text { "Well, the family's name is well known, as it is the same as the } \\
\text { company's name. This name is used in our day to day language } \\
\text { and has also an entry in the dictionary." (\#6 CleanComp.] }\end{array}$} \\
\hline \multicolumn{3}{|l|}{$\begin{array}{l}\text { "We want to grow, we also plan growth as a long-term goal and } \\
\text { communicate this accordingly within the company. This means } \\
\text { that everyone must or should contribute to this strategy accord- } \\
\text { ingly. That means that you know what the long-term goals } \\
\text { are and what the individual projects are, which are built up in } \\
\text { sub-projects, what is the big picture of the strategy and where } \\
\text { does the company want to go in } 4-5 \text { years. So in this respect } \\
\text { relatively transparent also in terms of the figures and also in } \\
\text { terms of the goals I would say." [\#13 FormComp.] }\end{array}$} \\
\hline $\begin{array}{l}\text { "Sustainable management is an essential part of the corporate } \\
\text { culture. The family-owned company stands by this social } \\
\text { responsibility." [Code of Conduct, CleanComp.] }\end{array}$ & Socioemotional wealth & \\
\hline $\begin{array}{l}\text { "The founder family supports a Kindergarten for the employees' } \\
\text { kids to ensure that there are cared for. Also they established } \\
\text { flexible working tomes and home-office. When we had a } \\
\text { nursing case at home, we could also get support and informa- } \\
\text { tion from an organization with that our company established a } \\
\text { cooperation years ago." [\#2 CableComp.] }\end{array}$ & & \\
\hline \multicolumn{3}{|l|}{$\begin{array}{l}\text { "I think it's important that the company has values and that } \\
\text { sometimes the heart has a stronger say than pure numbers. } \\
\text { This may not always make sense financially, but I think it's } \\
\text { important in the long run that the family's philosophy stays in } \\
\text { the organization." [\#11 FormComp.] }\end{array}$} \\
\hline \multicolumn{3}{|l|}{$\begin{array}{l}\text { "Of course we want to make profit and want to become better } \\
\text { and better. But in contrast to large DAX companies, we are } \\
\text { not focused on short-term quarterly numbers. If an investment } \\
\text { only pays-off in } 2,3 \text {, or } 5 \text { years this is all right. If you know } \\
\text { it. [...] We are not forced to look for short-term profits, but to } \\
\text { establish a solution which is sustainable in the long run." [\#2 } \\
\text { CableComp.] }\end{array}$} \\
\hline $\begin{array}{l}\text { "So, what I do believe is that the appreciation of the employee } \\
\text { within our company is different from that of the large corpora- } \\
\text { tions. Even if the figures were bad in the past, there was no } \\
\text { hiring freeze or a wave of layoffs. But the founder family } \\
\text { consciously said no, the last thing we do is kick out our good } \\
\text { employees. So you can already see that there is esteem." [\#7 } \\
\text { CleanComp.] }\end{array}$ & Employee focus & Values of founding family \\
\hline \multicolumn{3}{|l|}{$\begin{array}{l}\text { "For me, the identity of the firm is on one side the values, which } \\
\text { are derived from the family. [...] We want to ensure safe jobs } \\
\text { for our } 15.000 \text { employees, we want to invest and grow stable. } \\
\text { This for me is our identity." [\#10 FormComp.] }\end{array}$} \\
\hline $\begin{array}{l}\text { "The founder's wife told us how important it is that one is } \\
\text { healthy. The most important thing, she said, is a family which } \\
\text { supports oneself. Because you can also have as much energy at } \\
\text { work as you get from your family." [\#1 CableComp.] }\end{array}$ & & \\
\hline
\end{tabular}


Table 3 (continued)

\begin{tabular}{|c|c|c|}
\hline Quotes & 1st Order codes & 2nd Order categories \\
\hline $\begin{array}{l}\text { "But I would describe them [founder family] as very down-to- } \\
\text { earth and humble. And what I respect and think is good is } \\
\text { really }[\ldots] \text { they just stayed and live here in the region. And } \\
\text { also that he wants to keep the main location here on site. It is } \\
\text { a real commitment to the region and the employees. Also, the } \\
\text { founder's son says what he thinks and he is very sympathetic } \\
\text { and well connected in the organization-he almost knows } \\
\text { everyone by name." [\#20 VentilatorComp.] }\end{array}$ & \multirow[t]{3}{*}{ Humble } & \\
\hline $\begin{array}{l}\text { "When you eat in the canteen you often meet the founder. He } \\
\text { would sit with the technicians or other employees. He has lunch } \\
\text { with everyone. For me this is a sign that he is down-to-earth. } \\
\text { Different than other company patriarchs. [...]. He and his sister } \\
\text { are very open persons. Very sociable, and intelligent." [\#3 } \\
\text { CleanComp.] }\end{array}$ & & \\
\hline $\begin{array}{l}\text { "I am sure we are perceived as family firm by the public. We are } \\
\text { perceived as harmonic organization with focus on solidar- } \\
\text { ity and not on short-term profits like DAX-companies." [\#6 } \\
\text { CleanComp.] }\end{array}$ & & \\
\hline $\begin{array}{l}\text { "The fact that you are present as family business in our rural } \\
\text { region is another way of creating an identity. Identity in a sense } \\
\text { of being present, caring for and knowing the people in the } \\
\text { region. If the company wasn't there, the place would probably } \\
\text { be pretty dead and here's the company's identity that keeps the } \\
\text { place alive." [\#14 GlasComp.] }\end{array}$ & \multirow[t]{3}{*}{ Local connection } & \\
\hline $\begin{array}{l}\text { "The close connection with the region is important. We have } \\
\text { our roots here. The founder family wants to provide consist- } \\
\text { ency to the region and the employees. And our company } \\
\text { culture emphasizes the closeness to the founder family." [\#14 } \\
\text { GlasComp.] }\end{array}$ & & \\
\hline $\begin{array}{l}\text { "The family cares how the organization is perceived by external } \\
\text { stakeholders. [...] The family is committed to further produce } \\
\text { in Germany.[...]. This is an important message." [\#12 Form- } \\
\text { Comp.] }\end{array}$ & & \\
\hline $\begin{array}{l}\text { "To make that point again: in my view, the link to the founder } \\
\text { family is less important for the new employees. However, it } \\
\text { should be important because most of our actions and values } \\
\text { like visiting customer fair, emphasizing strong relationships } \\
\text { among employees, etc. are originating from the founding fam- } \\
\text { ily. These values are lived but the link to the founder family is } \\
\text { fallen into oblivion over time." [\#9 FormComp.] }\end{array}$ & \multirow[t]{4}{*}{ Organization linked to founder's identity } & \\
\hline $\begin{array}{l}\text { "I believe that the founder's influence is still high. He still lives } \\
\text { in the organization and shapes it via his value system.” [\#13 } \\
\text { FormComp.] }\end{array}$ & & \\
\hline $\begin{array}{l}\text { "The values of the founding family stand for the people aspect in } \\
\text { the organization." [\#18 VentilatorComp.] }\end{array}$ & & \\
\hline $\begin{array}{l}\text { "When the founder makes a Christmas speech he usually talks } \\
\text { about family, children, time with the families and so on. That } \\
\text { one must appreciate these moments. Extremely rarely he } \\
\text { says anything about numbers, dates, facts. That is left to our } \\
\text { management. There is already the feeling that there is a family } \\
\text { in the background, which still takes care and that the people do } \\
\text { not only care about the work." [\#5 CleanComp.] }\end{array}$ & & \\
\hline $\begin{array}{l}\text { "The family gives us the freedom to define long-term strategies. } \\
\text { Our current strategy is set-up with a 10-year time horizon. Try } \\
\text { to have such a planning horizon in a public company where you } \\
\text { need to report every half year and then probably do something } \\
\text { new." [\#3 CleanComp.] }\end{array}$ & Trust & \\
\hline
\end{tabular}


Table 3 (continued)

\begin{tabular}{l}
\hline Quotes \\
"For me as employee, family business means a strong culture that \\
is driven by family values on the one hand and organizational \\
culture on the other. This means that the entrepreneurial aspect \\
is not neglected. Also, short-term trends or return targets are \\
not made on a quarterly basis, but the owner family has the \\
strength and the will to pursue a topic for a longer time." [\#10 \\
FormComp.] \\
"We treat each other honestly. For example, I very rarely had \\
to deal with intrigues or with someone being dishonest. \\
Such behavior does not stay in the organization for long. The \\
organization is so strong, we sweat it out. And that is very, very \\
helpful. Because in many companies, it takes so much energy \\
away from the actual business. Some people don't care about \\
anything else anymore. This is a big advantage in our family \\
firm." [\#3 CleanComp.]
\end{tabular}

In line with long-term orientation and tradition, socioemotional wealth - that is, the focus on goals other than firm financial performance (Gómez-Mejía et al. 2007)_is an important identification characteristic of family firms. One of the companies in our sample, for instance, highlights in their code of conduct that sustainability is part of the firm's DNA: "Sustainable management is an essential part of the corporate culture. The family-owned company stands by this social responsibility" (Code of Conduct, CleanComp). One interviewee emphasizes the importance of the family philosophy besides financial performance:

I think it's important that the company has values and that sometimes the heart has a stronger say than pure numbers. This may not always make sense financially, but I think it's important in the long run that the family's philosophy stays in the organization. \#11, Channel Manager, FormComp.

(3) Visibility of the founding family: The presence and visibility of the founding family in the organization and day-to-day business influences the employees' perception of the organization. The more visible the founding family is, the more employees identify with them:

For me, it matters that it's still family run. The founder's wife - at 87 years - is still very committed to the organization. And she still transmits the family's values, like the importance of the health and the family. \#1, Customer Communication CableComp.
The founding family's presence impresses many of the interviewees. Such visibility supports employee identification with the family and the organization. As one interviewee states:

Of course, the owner family sometimes is involved at a different level than a pure external management team would be. Sometimes the founder gets involved in topics you simply can't believe. [...]. For example, he decided about the design of the packaging of our new product launch. \#8, Product Manager ColorComp.

This discussion of our findings suggests the following proposition:

Proposition 2 Family firm characteristics-such as values of the founding family, long-term orientation and socioemotional wealth, and the visibility of the founding family-strongly shape the identification processes of employees with the organization.

\section{Coping with Ethical Decisions}

The identity work of family firm employees also leads to a certain perception of ethical situations. Our data analysis shows that the family firm employees in our sample mostly have a common understanding of ethics, which reflects the company's values, as well as general Christian values. When ethical issues occur, an employee's identification with the organization and with the founding family often forms the 
basis for decision-making: Employees take into consideration how the founding family would decide and what would be best for the family firm. Their own identity also plays into the decision, as employees need to feel comfortable. One interviewee explained:

If you can sleep well at night. It doesn't matter what kind of decision you have to make, but you have to feel comfortable with it. If I can bring this together, then I think it's ethical or moral. \#11, Channel Manager, FormComp.

How family firm employees cope with ethical decisions thus appears to be influenced by a synthesis of how the two roles-private and professional (with strong links to the organization)-interact. We already revealed that family firm employees identify with the organization, so there is largely no mismatch between their own ethical awareness and motivation and that of the organization. This helps employees evaluate what is right and what is wrong. Table 4 provides an overview of exemplary codes and quotes; it summarizes different situations in which family firm employees are faced with ethical situations and how they react.

Family firm employees also encounter ethical situations opposing their own and the company's values. If trust towards customers and coworkers is betrayed or employees are dishonest, this is perceived to be unethical. One interviewee provided the following example:

Well, I'm making a promise I can't keep. And, the worst part is, I'm not gonna be open with you and say it. [...] So, if I promise you'll get the list by Friday and know that I just can't do it, then I'd better let ou know." \#17, Head of Marketing Europe, HotelComp.

Employees recognize such behavior goes against the company's values, but they also affirm that it is not tolerated in the organization. Individuals engaging in such activities are excluded from the organization very quickly. Often, there is not even a formal process for this, but as such behavior counters the internal value system, the organization applies its own informal measures. One interviewee described the following:

Whoever's doing this [corruption] is gonna be out of the organization pretty soon. And by the organization itself. Well, sometimes these things happen, for example a new employee comes in and you as the boss might not notice it at all, but he is totally arrogant, and he is such a know-it-all and he messes around with everything. The organization sweats him out, honestly. We've had cases like this before. They might stay a year, but that's as long as they stay. Then suddenly they're gone again. It's very rare that a guy like that that doesn't fit into the organization, that he stays in.
That is very rare. \#3, Head of Direct Export, CleanComp.

Thus, our final proposition is:

Proposition 3 The identity work of an individual towards (1) identifying as a family firm employee and (2) identifying with family firm characteristics influences how employees in family firms cope with ethical situations.

\section{Discussion}

Our research explores how an employee's identification with a family firm shapes ethical decision-making processes. Drawing on identity theory, we uncovered two main identification processes: individuals engage in identity work when they identify (1) as individual family firm employees and (2) with perceived family firm characteristics. These two identification processes shape how individuals approach ethical situations in business contexts.

\section{Theoretical Implications}

We now present our contributions to ethics research, the broader identity theory literature, and family business research. First, with our findings, we make a valuable contribution to ethics research by expanding our understanding of the roots of ethical decision-making in family firms. Our article provides the most rigorous articulation of the identification mechanisms that shape how employees cope with ethical (dilemma) situations. As illustrated by the diverse examples throughout the article, the perception of ethical situations is influenced by the identity work of employees. We used qualitative research techniques to create a conceptual model that explains how individuals engage in identity work and how this, in turn, influences how they cope with ethical situations. Our sample consisted of German family firms. Given that individuals themselves, not organizations, make moral choices (Stead et al. 1990), it was important to apply an individual-centric perspective in our research. How individuals cope with ethical situations in general is shaped by their personal values, beliefs, and ideals (Astrachan et al. 2020), while how they cope with ethical situations in business contexts is shaped by their socialization into an organization (Stead et al. 1990). Our study shows that employees of family firms aim for high congruence between the founding family's values and their own. Employees are embedded in an organizational background against which they construct subjective meanings and experiences, which helps them identify with the firm (Alvesson et al. 2008). They blend their personal and professional lives, which increases 
Table 4 Coping with ethical situations

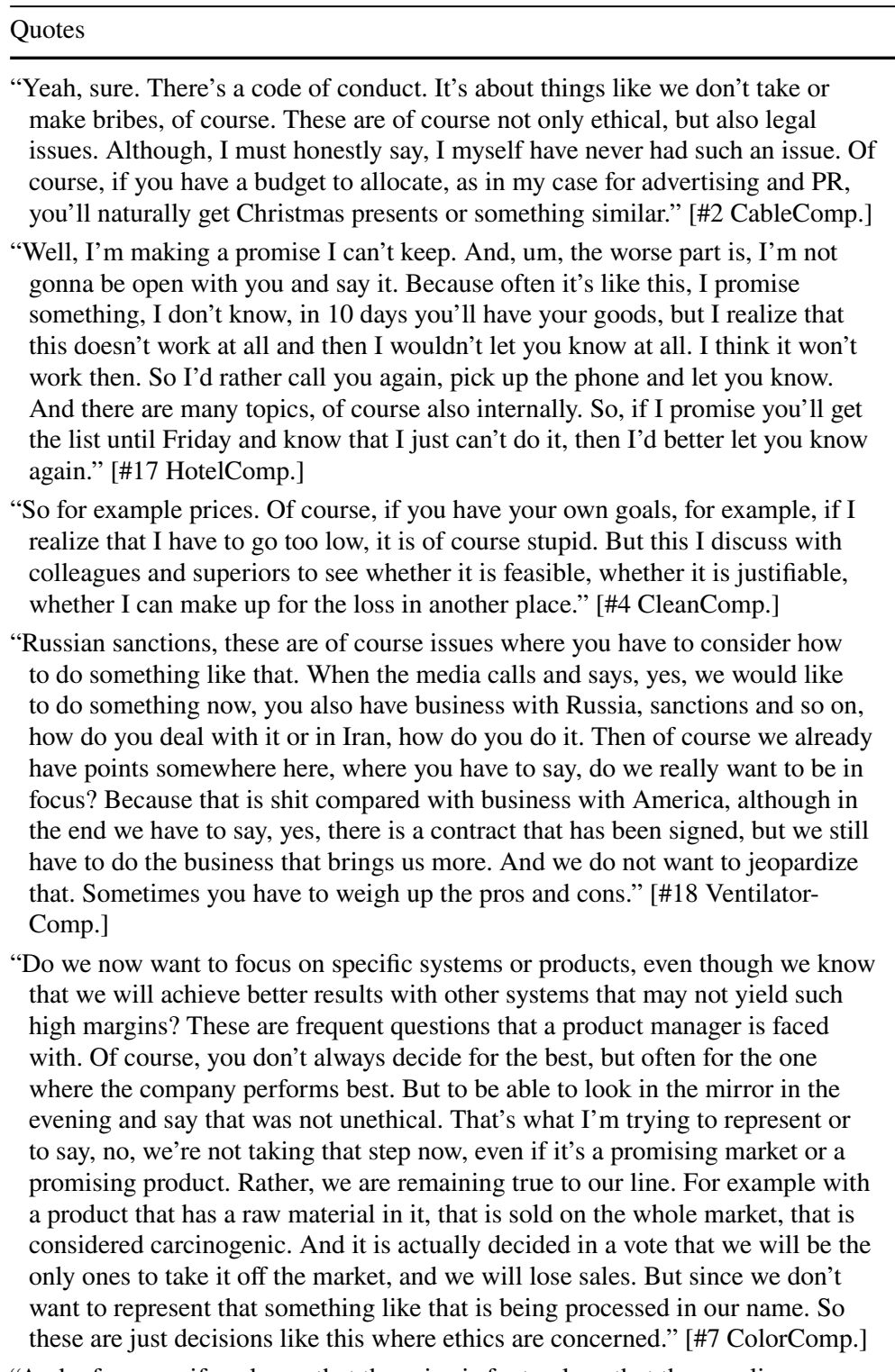

"And, of course, if we know that the price is far too low, that the supplier can survive with it, that is also an ethical decision to say that we do not support this supplier. Because we cannot accept it for this price, because we know that in the medium term it will ruin the supplier. We also always tell our suppliers that we do not actually want to be responsible for $90 \%$ of their turnover, because on the one hand, of course, this gives them an enormous negotiating leverage, and on the other hand, if we want to withdraw our business from them, then they are actually facing ruin, and that is something we want to prevent in general." [\#3 CleanComp.]

"I define unethical behavior as acting against requirements with full conscience. [...] For example, if I would say that everything is fine at one supplier when in fact it is not. This would be a no-go for me." [\#17 GlasComp.]

"But it's not just my department, but across teams: For innovation projects we have a very clear process of how an innovation project has to run. And it's the team that takes a cross-functional look at it. Has the developer done all the necessary checks? In the past, you might have said that we first go to the market and follow up the tests. Or that the purchasing department checks whether all certificates are available for all raw materials, for example. Of course, such tests have been done in the past. But maybe not with the intensity you do now." [\#7 ColorComp.] 1st Order codes

2nd Order categories

Behavior towards clients

Ethical dilemma situations
Ethics focus on supplier Organization does not tolerate
unethical behavior 
Table 4 (continued)

\begin{tabular}{|c|c|c|}
\hline Quotes & 1st Order codes & 2nd Order categories \\
\hline \multicolumn{3}{|l|}{$\begin{array}{l}\text { "Anything with dishonesty in it. A lie to omit something is always one of those } \\
\text { things. If it really is the basis for the other person, I find it critical if I conceal } \\
\text { something from him that he needs to know in order to be able to make the deci- } \\
\text { sion properly. As long as it is something where I say that it is really detached, } \\
\text { then it can work for me. Um, like I said, clearly where someone is harmed in } \\
\text { the end. Whether it's through a lie or really not informing them. or to really } \\
\text { decide to his disadvantage." [\#8 ColorComp.] }\end{array}$} \\
\hline \multicolumn{3}{|l|}{$\begin{array}{l}\text { "Whoever's doing this is [corruption] gonna be out of the organization pretty } \\
\text { soon. And by the organization itself. Well, sometimes these things happen, for } \\
\text { example a new employee comes in and you as the boss might not notice it at } \\
\text { all, but he is totally arrogant and he is such a know-it-all and he messes around } \\
\text { with everything. The organization sweats him out, honestly. We've had cases } \\
\text { like this before. They might stay a year, but that's as long as they stay. Then } \\
\text { suddenly they're gone again. It's very rare that a guy like that doesn't fit into the } \\
\text { organization, that he stays in. That is very rare." [\#3 CleanComp.] }\end{array}$} \\
\hline \multicolumn{3}{|l|}{$\begin{array}{l}\text { "Yes, well, unethical behavior is actually anything that violates any ethical prin- } \\
\text { ciples. Whether it is a business background or a scientific or personal one, it } \\
\text { doesn't really matter. But anything that contradicts our values or norms, norms } \\
\text { may be wrong, but values that contradict values, that is actually, that is actually } \\
\text { unethical behavior. And we are also very allergic to this, I must honestly say. I } \\
\text { have just now such a case on the table, where we had a lot of phone calls with } \\
\text { our managing directors from the USA. There had been rumors that one of our } \\
\text { coworkers spread anti-democratic slogans. And I spoke with this person." [\#3 } \\
\text { CleanComp.] }\end{array}$} \\
\hline $\begin{array}{l}\text { "I experienced a situation where an indirect supervisor put a lot of pressure on } \\
\text { me. We had an issue with an employee and he wanted me to fire this employee. } \\
\text { For me this was at the boundary-the pressure was higher in this organizational } \\
\text { situation than if I would have decided all by myself." [\#11 FormComp.] }\end{array}$ & Unethical behavior of employees & \\
\hline $\begin{array}{l}\text { "We once had to let an employee go because we realized that he was betraying } \\
\text { us. That was certainly not so easy, because the decision is not made easily." [\#3 } \\
\text { CleanComp.] }\end{array}$ & & \\
\hline \multicolumn{3}{|l|}{$\begin{array}{l}\text { "In personnel decisions it is always a dilemma. Because it is always the question, } \\
\text { for example, can I develop the employee to where I want him to be? Or do I } \\
\text { have to part with him without knowing what comes next or who will follow. } \\
\text { I think that's always a bit of a dilemma, even if you have an employee who } \\
\text { doesn't perform as well as you would like him to. The question, what can you } \\
\text { get out of it or should you split up." [\#17 GlasComp.] }\end{array}$} \\
\hline $\begin{array}{l}\text { [Situation: Management asked interviewee in her former role as internal audit to } \\
\text { make up things about another employee such that management would have a } \\
\text { reason to set this employee free]. "It happened to me once or twice that I had } \\
\text { the feeling that they [management] wanted to use me or my role for something } \\
\text { in the gray zone-I always refused." [\#16 HotelComp.] }\end{array}$ & & \\
\hline
\end{tabular}

their sense of belonging to the family firm; this sense of belonging leads to a strong identification as a family firm employee and as a member of the organization. These two processes of identification stimulate each other and shape how an individual employee copes with ethical situations (as illustrated in Fig. 1). Overall, this is an important step to bridge the two perspectives of identity and ethical behavior (Dieleman and Koning 2020).

Second, we add to the rich existing theoretical literature on identity work. We analyzed how individuals identify as family firm employees and with perceived family firm characteristics. As extant research reveals, the forms of identity work vary (Ibarra and Barbulescu 2010), and with our research we highlight two important forms of identification processes within family firms as part of employees' ongoing identity work. We do this partly by providing more details on the interplay between individuals, their identification as family firm employees, and their identification with the organization. We thus especially extend research on identity work by revealing how individuals establish their identity as a family firm employee. We also focus on externally oriented identity work, which is influenced by family firm characteristics. It has long been accepted that individuals need to negotiate their social identities (which result from, e.g., organizational memberships) and their personal identities, but little is known about the underlying process (Kreiner 
et al. 2006). Our model provides insight into the very process of identification. Identity theory in particular allowed us to explore how employees identify with their family firm. Our conceptual model illustrates the drivers behind such identification processes. Our analysis especially emphasizes an important set of family firm characteristics that shape family firm employees' identity work. As such, the article extends theory on identity work by demonstrating the facets of two of its forms in family firms.

Third, we add a new facet to research on family firms. Assuming an identity theory perspective, we also respond to recent calls in family firm research to integrate the "theoretical and empirical insights from psychology to further advance our knowledge on family businesses" and to leverage the potential inherent in such analyses (Kammerlander and Breugst 2019, p. 222). With our study, we also extend the findings of Vazquez (2016), who identified three critical aspects of ethical behavior in family firms: "involvement of the owning family, socioemotional wealth, and typical social interaction" (p. 705). Moreover, we connect to Dieleman and Koning (2020), who were among the first to bridge identity work and (un)ethical behavior in the context of family firms. We also expand past research that often investigated the individual employee or the organizational context of family businesses in isolation (Treviño et al. 2006). We incorporate not only the individual employee, but also characteristics of the (founding) family and the firm. This approach relates to a more unified systems perspective, which "views the family business as a meta-system of the family, the business, and the individual members" (Knapp et al. 2013, p. 333). This unified perspective allows us to acknowledge how individual factors (e.g., personal values) enhance or diminish the value of organizational factors (e.g., founding family values) for ethical decision-making - and vice versa.

\section{Practical Implications}

As ethical (mis)behavior causes substantial financial and reputational damage to businesses, sustaining ethical operations is of utmost relevance for practitioners (e.g., Fichter 2018; Kvalnes and Nordal 2018; Lin-Hi and Blumberg 2018). Thus, our findings are valuable for general management as they reveal how unique family firm characteristics influence employee approaches to (un)ethical decisionmaking. To some extent, it is still the individual person who exerts moral responsibility in such situations, driven by own personal values, norms, and beliefs. However, our study highlights that individual employees' identification with family firm characteristics shapes how employees behave in ethical situations. Our study emphasizes that ethical decisions are always embedded in an environment. Ethical decisions in business contexts are thus always embedded in an organizational framework. Our research suggests that family firms should actively shape this organizational context to foster or maintain ethical behavior. For instance, employees of family firms should have access to and a good understanding of the family firm's value system. This is necessary for individual employees to be able to compare their personal values with those of the firm and to determine whether they behave (un)ethically according to the family firm's value system.

The visibility of the founding family as well as the longterm orientation and socioemotional wealth perspective are further important aspects that help employees to identify strongly with the organization. Our interviews reveal that it is highly important for employees to see members of the founding family or later generations in the $\mathrm{C}$-suite or on the board of directors. Family firm employees furthermore strive to blend their private with their professional lives, which hints at another practical implication: firms could actively offer infrastructure (e.g., kindergarten, fitness facilities) or events (e.g., team building) to facilitate such blending. In sum, we find that the unique family firm characteristics function as an informal management mechanism that shapes employees' approach to (un)ethical situations.

\section{Research Limitations and Future Research}

We arrive at novel and valuable insights into the relation between identification processes and ethical decision-making in family firms. In terms of the generalizability of our research - it was our primary focus to obtain an insightful and rich understanding of ethical behavior in family firms. Therefore, we started with a well-selected data set, which is in line with current standards (e.g., Salvato and Corbetta 2013). However, we acknowledge the interviews conducted with a sample of 19 family firm employees allow only limited interpretations of the connection between identity and ethical behavior. Given that our study is limited to German family firms, our findings could be subject to bias due to the single-nation focus. Each nationality and culture has different values, and individuals' ethical awareness could be influenced by their cultural background. To gain a more detailed understanding, we suggest taking our research as a basis to explore further the family firm's unique characteristics and ethical behavior against other cultural settings. For instance, Cruz (2020) has recently revealed contradictions between family and external expectations of Corporate Social Responsibility reporting measures in Latin American family businesses. From an ethics perspective, we did not assess examples of (un)ethical behavior. An (objective) assessment and evaluation of actual (un)ethical behavior is an important next step to interpret whether or not the approach to an ethical situation is congruent with the underlying value system. 
We also call for future research to examine the temporal dimension of identification, an important facet which is rarely studied. As our results show, identification is not static but dynamic in nature. Identification processes involve many aspects, both on the individual and organizational level. Identifying with an organization and its values is an ongoing journey for employees. Some parts of an individual's identity even evolve along with the sense of belonging to an organization, which needs further investigation (Knapp et al. 2013; Kreiner et al. 2006).

Future research could also explore the impact meaningful work has on the ethical decision-making of family firm employees. Employees are highly motivated to engage in meaningful and long-lasting work. Scholars could thus combine the ethical behavior literature with the research stream of meaningful work to gather insights (Bailey et al. 2019; Lysova et al. 2019). The meaningfulness of work is an individual evaluation of the personal fulfillment derived from the roles and tasks employees perform (Kreiner et al. 2006), and the perspective of meaningful work could shed light on why employees perceive some ethical situations and how ethical awareness alters with the perceived meaningfulness of the work.

Funding Open Access funding enabled and organized by Projekt DEAL.

\section{Compliance with Ethical Standards}

Conflict of interest The authors declare that they have no conflicts of interest.

Open Access This article is licensed under a Creative Commons Attribution 4.0 International License, which permits use, sharing, adaptation, distribution and reproduction in any medium or format, as long as you give appropriate credit to the original author(s) and the source, provide a link to the Creative Commons licence, and indicate if changes were made. The images or other third party material in this article are included in the article's Creative Commons licence, unless indicated otherwise in a credit line to the material. If material is not included in the article's Creative Commons licence and your intended use is not permitted by statutory regulation or exceeds the permitted use, you will need to obtain permission directly from the copyright holder. To view a copy of this licence, visit http://creativecommons.org/licenses/by/4.0/.

\section{References}

Albert, S., Ashforth, B. E., \& Dutton, J. (2000). Organizational identity and identification: Charting new waters and building bridges. Academy of Management Review, 25(1), 13-17.

Albert, S., \& Whetten, D. A. (1985). Organizational identity. Research in Organizational Behavior, 7, 263-295.

Alvesson, M., Ashcraft, K. L., \& Thomas, R. (2008). Identity matters: Reflections on the construction of identity scholarship in organization studies. Organization, 15(1), 5-27.
Anderson, R. C., \& Reeb, D. M. (2003). Founding-family ownership and firm performance: Evidence from the S\&P 500. The Journal of Finance, 58(3), 1301-1328.

Astrachan, J. H., Binz Astrachan, C., Campopiano, G., \& Baù, M. (2020). Values, spirituality and religion: Family business and the roots of sustainable ethical behavior. Journal of Business Ethics, 163(4), 637-645.

Bailey, C., Yeoman, R., Madden, A., Thompson, M., \& Kerridge, G. (2019). A review of the empirical literature on meaningful work: Progress and research agenda. Human Resource Development Review, 18(1), 83-113.

Bansal, P. T., \& Corley, K. (2012). Publishing in AMJ-Part 7: What's different about qualitative research? Academy of Management Journal, 55(3), 509-513.

Barbera, F., Shi, H. X., Agarwal, A., \& Edwards, M. (2020). The Family that prays together stays together: Toward a process model of religious value transmission in family firms. Journal of Business Ethics, 163(4), 661-673.

Berrone, P., Gómez-Mejía, L. R., \& Larraza, M. (2010). Socioemotional wealth and corporate responses to institutional pressures: Firms pollute less? Administrative Science Quarterly, 55(1), 82-113.

Bhatnagar, N., Sharma, P., \& Ramachandran, K. (2020). Spirituality and corporate philanthropy in Indian family firms: An exploratory study. Journal of Business Ethics, 163(4), 715-728.

Blodgett, M. S., Dumas, C., \& Zanzi, A. (2011). Emerging trends in global ethics: A comparative study of U.S. and international family business values. Journal of Business Ethics, 99(1), 29-38.

Brown, M. E., Treviño, L. K., \& Harrison, D. A. (2005). Ethical leadership: A social learning perspective for construct development and testing. Organizational Behavior and Human Decision Processes, 97(2), 117-134.

Carradus, A., Zozimo, R., \& Discua Cruz, A. (2020). Exploring a faithled open-systems perspective of stewardship in family businesses. Journal of Business Ethics, 163(4), 701-714.

Charmaz, K. (2014). Constructing grounded theory. Thousand Oaks, CA: Sage.

Chau, L. L., \& Siu, W. (2000). Ethical decision-making in corporate entrepreneurial organizations. Journal of Business Ethics, 23, $365-375$.

Chenail, R. J. (2009). Communicating your qualitative research better. Family Business Review, 22(2), 105-108.

Colli, A., Pérez, P. F., \& Rose, M. B. (2003). National determinants of family firm development? Family firms in Britain, Spain, and Italy in the nineteenth and twentieth centuries. Enterprise \& Society, $4(1), 28-64$

Craft, J. L. (2013). A review of the empirical ethical decision-making literature: 2004-2011. Journal of Business Ethics, 117(2), 221-259.

Cremer, D. D., Mayer, D. M., \& Schminke, M. (2010). On understanding ethical behavior and decision making: A behavioral ethics approach. Business Ethics Quarterly, 20(1), 1-6.

Cullen, J. B., Victor, B., \& Bronson, J. W. (1993). Ethical climate questionnaire: An assessment of its development and validity. Psychological Reports, 73, 667-674.

De Massis, A., \& Kotlar, J. (2014). The case study method in family business research: Guidelines for qualitative scholarship. Journal of Family Business Strategy, 5(1), 15-29.

Dieleman, M., \& Koning, J. (2020). Articulating values through identity work: Advancing family business ethics research. Journal of Business Ethics, 163(4), 675-687.

Discua Cruz, A. (2020). There is no need to shout to be heard! The paradoxical nature of corporate social responsibility (CSR) reporting in a Latin American family small and medium-sized enterprise 
(SME). International Small Business Journal: Researching Entrepreneurship, 38(3), 243-267.

Dubinsky, A., \& Loken, B. (1989). Ethical decision making in marketing. Journal of Business Research, 19, 83-107.

Duh, M., Belak, J., \& Milfelner, B. (2010). Core values, culture and ethical climate as constitutional elements of ethical behaviour: Exploring differences between family and non-family enterprises. Journal of Business Ethics, 97(3), 473-489.

Dyer, W. G., \& Whetten, D. A. (2006). Family firms and social responsibility: Preliminary evidence from the S\&P 500. Entrepreneurship, 801, 785-803.

Eisenhardt, M. (1989). Agency theory: An assessment review. The Academy of Management Review, 14(1), 57-74.

Eury, J. L., Kreiner, G. E., Treviño, L. K., \& Gioia, D. A. (2018). The past is not dead: Legacy identification and alumni ambivalence in the wake of the Sandusky scandal at Penn State. Academy of Management Journal, 61(3), 826-856.

Everett, W. J. (1986). OIKOS: Convergence in business ethics. Journal of Business Ethics, 5(4), 313-325.

Evert, R. E., Martin, J. A., McLeod, M. S., \& Payne, G. T. (2016). Empirics in family business research: Progress, challenges, and the path ahead. Family Business Review, 29(1), 17-43.

Fathallah, R., Sidani, Y., \& Khalil, S. (2020). How religion shapes family business ethical behaviors: An institutional logics perspective. Journal of Business Ethics, 163(4), 647-659.

Ferrell, O. C., Crittenden, V. L., Ferrell, L., \& Crittenden, W. F. (2013). Theoretical development in ethical marketing decision making. AMS Review, 3(2), 51-60.

Fichter, R. (2018). Do the right thing! Developing ethical behavior in financial institutions. Journal of Business Ethics, 151(1), 69-84.

Fletcher, D., Massis, A. D., \& Nordqvist, M. (2016). Qualitative research practices and family business scholarship: A review and future research agenda. Journal of Family Business Strategy, 7(1), $8-25$.

Gallo, M. A. (2004). The family business and its social responsibilities. Family Business Review, 17(2), 135-148.

Gephart, R. P. (2004). What is qualitative research and why is it important? Academy of Management Journal, 47(4), 454-462.

Gioia, D. A., \& Chittipeddi, K. (1991). Sensemaking and sensegiving in strategic change initiation. Strategic Management Journal, 12(6), 433-448.

Gómez-Mejía, L. R., Takács, K., Núñez-Nickel, M., Jacobson, K. J. L., \& Moyana-Fuentes, J. (2007). Socioemotional wealth and business risks in family-controlled firms: Evidence from Spanish olive oil mills. Administrative Science Quarterly, 52(1), 106-137.

Gorsira, M., Denkers, A., \& Huisman, W. (2018). Both sides of the coin: Motives for Corruption among public officials and business employees. Journal of Business Ethics, 151(1), 179-194.

Gottschalk, D. S., Egeln, J., Kinne, J., Hauer, A., Keese, D. D., and Oehme, M. (2017). Die volkswirtschaftliche Bedeutung der Familienunternehmen. Leibniz-Zentrum für Europäische Wirtschaftsforschung/Institut für Mittelstandsforschung, Mannheim

Hernández-Linares, R., Sarkar, S., \& Cobo, M. J. (2018). Inspecting the Achilles heel: A quantitative analysis of 50 years of family business definitions. Scientometrics, 115(2), 929-951.

Hogan, V.D.-M.T., Clinton, E., \& Brophy, M. (2019). Defining family business: A closer look at definitional heterogeneity. In E. Memili \& C. Dibrell (Eds.), The palgrave handbook of heterogeneity among family firms (pp. 333-374). London: Palgrave.

Howorth, C., Rose, M., Hamilton, E., \& Westhead, P. (2010). Family firm diversity and development: An introduction. International Small Business Journal, 28(5), 437-451.

Hunt, S. D., \& Vitell, S. (1986). A general theory of marketing ethics. Journal of Macromarketing, 6(1), 5-16.

Ibarra, H., \& Barbulescu, R. (2010). Identity as narrative: Prevalence, effectiveness, and consequences of narrative identity work in macro work role transitions. Academy of Management Review, $35(1), 135-154$

Jones, T. M. (1991). Ethical decision making by individuals in organizations: An issue-contingent model. The Academy of Management Review, 16(2), 366-395.

Kammerlander, N., \& Breugst, N. (2019). Construals matter: Painting the big picture or drawing the brushstrokes of the family firm. Family Business Review, 32(3), 222-232.

Kashmiri, S., \& Mahajan, V. (2014). A rose by any other name: Are family firms named after their founding families rewarded more for their new product introductions? Journal of Business Ethics, 124(1), 81-99.

Kavas, M., Jarzabkowski, P., \& Nigam, A. (2020). Islamic family business: The constitutive role of religion in business. Journal of Business Ethics, 163(4), 689-700.

Knapp, J. R., Smith, B. R., Kreiner, G. E., Sundaramurthy, C., \& Barton, S. L. (2013). Managing boundaries through identity work: The role of individual and organizational identity tactics. Family Business Review, 26(4), 333-355.

Kreiner, G. E., Hollensbe, E. C., \& Sheep, M. L. (2006). Where is the "me" among the "we"? Identity work and the search for optimal balance. Academy of Management Journal, 49(5), 1031-1057.

Kreiner, G., Hollensbe, E., \& Sheep, M. (2009). Balancing borders and bridges: Negotiating the work-home interface via boundary work tactics. Academy of Management Journal, 52(4), 704-730.

Krishnan, G., \& Peytcheva, M. (2019). The risk of fraud in family firms: Assessments of external auditors. Journal of Business Ethics, 157(1), 261-278.

Kvalnes, Ø., \& Nordal, S. (2018). Normalization of questionable behavior: An ethical root of the financial crisis in Iceland. Journal of Business Ethics, 159(3), 1-15.

Lehnert, K., Craft, J., Singh, N., \& Park, Y. H. (2016). The human experience of ethics: A review of a decade of qualitative ethical decision-making research. Business Ethics, 25(4), 498-537.

Lehnert, K., Park, Y., \& Singh, N. (2015). Research note and review of the empirical ethical decision-making literature: Boundary conditions and extensions. Journal of Business Ethics, 129(1), 195-219.

Leppäaho, T., Plakoyiannaki, E., \& Dimitratos, P. (2016). The case study in family business: An analysis of current research practices and recommendations. Family Business Review, 29(2), 159-173.

Lin-Hi, N., \& Blumberg, I. (2018). The link between (not) practicing CSR and corporate reputation: Psychological foundations and managerial implications. Journal of Business Ethics, 150(1), 185-198.

Long, R. G., \& Mathews, K. M. (2011). Ethics in the family firm: Cohesion through reciprocity and exchange. Business Ethics Quarterly, 21(2), 287-308.

Lubinski, C. (2011). Path dependency and governance in German family firms. Business History Review, 85(4), 699-724.

Lysova, E. I., Allan, B. A., Dik, B. J., Duffy, R. D., \& Steger, M. F. (2019). Fostering meaningful work in organizations: A multilevel review and integration. Journal of Vocational Behavior, 110, 374-389.

Martín Castejón, P. J., \& Aroca López, B. (2016). Corporate social responsibility in family SMEs: A comparative study. European Journal of Family Business, 6(1), 21-31.

Mayer, B., Trommsdorff, G., Kagitcibasi, C., \& Mishra, R. C. (2012). Family models of independence/interdependence and their intergenerational similarity in Germany, Turkey, and India. Family Science, 3(1), 64-74.

Mcferran, B., Aquino, K., \& Duffy, M. K. (2010). How personality and moral identity relate to individuals ' ethical ideology. Business Ethics Quarterly, 20(01), 35-56. 
McGuire, J., Dow, S., \& Ibrahim, B. (2012). All in the family? Social performance and corporate governance in the family firm. Journal of Business Research, 65(11), 1643-1650.

Memili, E., \& Dibrell, C. (2018). The Palgrave handbook of heterogeneity among family firms. London: Palgrave.

Miles, M., \& Huberman, M. (1994). Qualitative data analysis: A methods sourcebook. Thousand Oaks, CA: Sage.

Palazzo, B. (2002). U.S. American and German business ethics: An intercultural comparison. Journal of Business Ethics, 41(3), 195-216.

Payne, D., \& Joyner, B. E. (2006). Successful U.S. entrepreneurs: Identifying ethical decision-making and social responsibility behaviors. Journal of Business Ethics, 65(3), 203-217.

Peng, M. W., Sun, W., Vlas, C., Minichilli, A., \& Corbetta, G. (2018). An institution-based view of large family firms: A recap and overview. Entrepreneurship, 42(2), 157-205.

Pérez-González, F. (2006). Inherited control and firm performance. The American Economic Review, 96(5), 1559-1588.

Perrini, F., \& Minoja, M. (2007). Strategizing corporate social responsibility: Evidence from an Italian medium-sized, family-owned company. Business Ethics: A European Review, 17(1), 47-63.

Pratt, M. (2009). From the editors: For the lack of a boilerplate: Tips on writing up (and reviewing) qualitative research. Academy of Management Journal, 52(5), 856-862.

Pratt, M. G., Schultz, M., Ashforth, B. E., \& Ravasi, D. (2016). The Oxford handbook of organizational identity. Oxford: Oxford University Press.

Rest, J. R. (1986). Moral development: Advances in Research and theory. New York: Praeger.

Rubino, F. E., Tenuta, P., \& Cambrea, D. R. (2017). Board characteristics effects on performance in family and non-family business: a multi-theoretical approach. Journal of Management \& Governance, 21(3), 623-658.

Salvato, C., \& Corbetta, G. (2013). Transitional leadership of advisors as a facilitator of successors' leadership construction. Family Business Review, 26(3), 235-255.

Schwartz, M. S. (2016). Ethical decision-making theory: An integrated approach. Journal of Business Ethics, 139(4), 755-776.

Sharma, D. (2018). When fairness is not enough: Impact of corporate ethical values on organizational citizenship behaviors and worker alienation. Journal of Business Ethics, 150(1), 57-68.

Sharma, P., \& Sharma, S. (2011). Drivers of proactive environmental strategy in family firms. Business Ethics Quarterly, 21(2), 309-334.

Sigh, J. J., Iglesias, O., \& Batista-Fouget, J. M. (2012). Does having an ethical brand matter? The influence of consumer perceived ethicality on trust, Affect and Loyalty. Journal of Business Ethics, 111(4), 541-549.
Smith, M. L. (2014). Publishing qualitative research. Family Business Review, 27(2), 95-102.

Stead, W. E., Worrell, D. L., \& Stead, J. G. (1990). An integrative model for understanding and managing ethical behavior in business organizations. Journal of Business Ethics, 9(3), 233-242.

Stets, J., \& Burke, P. (2000). Identity theory and social identity theory. Social Psychology Quarterly, 63(3), 224-237.

Sundaramurthy, C., \& Kreiner, G. E. (2008). Governing by managing identity boundaries: The case of family businesses. Entrepreneurship, 32(3), 415-436.

Tajfel, H. (1978). Differentiation between social groups: Studies in the social psychology of intergroup relations. London: Academic Press.

Treviño, L. K., Den Nieuwenboer, N. A., \& Kish-Gephart, J. J. (2014). (Un)Ethical behavior in organizations. Annual Review of Psychology, 65, 635-660.

Treviño, L. K., Weaver, G. R., \& Reynolds, S. J. (2006). Behavioral ethics in organizations: A review. Journal of Management, 32(6), 951-990.

Treviño, L. K. (1986). Ethical decision making in organizations: A person-situation interactionist model. The Academy of Management Review, 11(3), 601-617.

Treviño, L. K. (1990). A cultural perspective on changing and developing organizational ethics. Research in Organizational Change and Development, 4(2), 195-230.

Treviño, L. K., \& Brown, M. E. (2004). Managing to be ethical: Debunking five business ethics myths. Academy of Management Executive, 18(2), 69-83.

Van Gils, A., Dibrell, C., Neubaum, D. O., \& Craig, J. B. (2014). Social issues in the family enterprise. Family Business Review, 27(3), 193-205.

Vazquez, P. (2016). Family Business Ethics: At the crossroads of business ethics and family business. Journal of Business Ethics, 150(3), 691-709.

Walsh, G., Mitchell, V. W., Jackson, P. R., \& Beatty, S. E. (2009). Examining the antecedents and consequences of corporate reputation: A customer perspective. British Journal of Management, 20(2), 187-203.

Yin, R. K. (1994). Case study research-design and methods. Thousand Oaks, CA: Sage.

Zellweger, T. M., Eddleston, K. A., \& Kellermanns, F. W. (2010). Exploring the concept of familiness: Introducing family firm identity. Journal of Family Business Strategy, 1(1), 54-63.

Publisher's Note Springer Nature remains neutral with regard to jurisdictional claims in published maps and institutional affiliations. 